Oikos 119: 337-349, 2010

doi: $10.1111 / \mathrm{j} .1600-0706.2009 .17862 . x$,

(C) 2009 The Authors. Journal compilation (C) 2009 Oikos

Subject Editor: Jennifer Rudgers. Accepted 20 July 2009

\title{
Nutrient supply and bird predation additively control insect herbivory and tree growth in two contrasting forest habitats
}

\author{
Lucas A. Garibaldi, Thomas Kitzberger, C. Noemí Mazía and Enrique J. Chaneton \\ L. A. Garibaldi (garibald@agro.uba.ar) and T. Kitzberger, Laboratorio Ecotono, INIBIOMA-CONICET and CRUB, Univ. Nacional del \\ Comahue, Quintral 1250, AR-8400 Bariloche, Río Negro, Argentina. LAG also at: Cátedra de Métodos Cuantitativos Aplicados, Facultad de \\ Agronomia, Univ. de Buenos Aires, Av. San Martín 4453, AR-1417 Buenos Aires, Argentina. - C. N. Mazia, Cátedra de Dasonomía, \\ Facultad de Agronomía, Univ. de Buenos Aires, Av. San Martín 4453, AR-1417 Buenos Aires, Argentina. - E. J. Chaneton, IFEVA- \\ CONICET and Facultad de Agronomía, Univ. de Buenos Aires, Av. San Martín 4453, AR-1417 Buenos Aires, Argentina.
}

\begin{abstract}
It has been suggested that bottom-up and top-down forces interactively control food web dynamics. While top-down effects would increase with resource availability to plants, bottom-up effects would be stronger under low predator abundance. These predictions, however, have rarely been tested at contrasting sites while keeping the dominant plant species unchanged. Furthermore, few studies have factorially manipulated both types of forces in forest communities. For two years, we evaluated the effects of fertiliser (NPK) addition and bird exclusion on tree growth, leaf traits, insect abundance, and folivory rates in a dry/warm and a wet/cold Nothofagus pumilio forest in Patagonia, Argentina. Overall, we found no interaction between nutrient supply and bird predation, although the strength of bottom-up and top-down forces differed markedly between forest sites. Treatment effects were generally weak in the wet forest, where tree growth rates and insect herbivory were low relative to the dry forest. In the dry forest, fertilisation increased sapling growth, insect abundance and folivory, whereas bird exclusion increased leaf damage and reduced tree growth. In the wet forest, fertilisation enhanced leaf nutrient contents and folivore abundance but not sapling growth, while bird exclusion had little impact on insects or trees. These results imply that factors other than nutrients and birds were important in controlling tree growth and folivore activity in the wet forest. While treatment effect sizes varied widely among feeding guilds, in general, nutrient effects on folivores were stronger than predator effects. We conclude that, within the timeframe of this study, tree growth and herbivory were additively affected by soil nutrients and predator presence, as bird exclusion effects did not change with elevated folivore activity on fertilised trees. We also show that both top-down and bottom-up cascades were weaker in a forest site characterised by slow-growing juvenile trees subjected to low folivore pressure.
\end{abstract}

It is now generally accepted that top-down and bottomup factors are both important in structuring ecological communities, and that their relative roles can vary widely among systems (Hunter and Price 1992, Polis 1999, Shurin et al. 2002). What remains unclear is when and where top-down and bottom-up forces should become strong or weak (Gripenberg and Roslin 2007). This is particularly true in terrestrial systems, for which empirical evidence is still sparse as to draw solid generalisations (Shurin et al. 2002, Borer et al. 2006, Gruner et al. 2008). It has been argued that the strength of top-down effects depends on the amount of bottom-up limitation to primary producers (Oksanen et al. 1981, Hunter and Price 1992, Abrams 1993, Worm et al. 2002, Borer et al. 2005). To examine this hypothesis, interactions between predator pressure and resource supply should be tested

The review of and decision to publish this paper has been taken by the above noted SE. The decision by the handling SE is shared by a second SE and the EiC. within different habitats (Menge et al. 2002). Yet, few studies so far have factorially manipulated top-down (carnivores) and bottom-up (resources) forces in contrasting sites of the same system (Moon and Stiling 2004, Albarracín and Stiling 2006).

Trophic dynamic theory suggests that top-down and bottom-up processes act interactively, in the sense that the magnitude of predator direct and indirect effects on lower trophic levels increases with resource inputs to plants (Oksanen et al. 1981, Hunter and Price 1992, Leibold et al. 1997). Conversely, effects of abiotic resources on herbivore abundance and impact on food plants would be stronger under low carnivore pressure (Oksanen et al. 1981, Moran and Scheidler 2002, Worm et al. 2002). The interdependence of top-down and bottom-up forces has been explored at two scales: within and among habitats (Borer et al. 2006). Several studies in terrestrial and coastal communities have tested for effects of predator exclusion (Schmitz et al. 2000, Halaj and Wise 2001) or nutrient addition (Ritchie 2000, Gratton and Denno 2003) within a 
site, but few experiments examined both factors concurrently (Stiling and Rossi 1997, Forkner and Hunter 2000, Denno et al. 2002, Moon and Stiling 2002, Moran and Scheidler 2002, Gruner 2004). Others have examined the strength of top-down forces across habitats differing in productivity or abiotic stress (Chase 1996, Preszler and Boecklen 1996, Schädler et al. 2003, Mazía et al. 2004). Taken as a whole, however, current evidence for the interactive nature of top-down and bottom-up forces is far from conclusive (Borer et al. 2006, Gruner et al. 2008).

Site comparisons of trophic regulation are often confounded by differences in plant and herbivore species composition (Borer et al. 2006). Different guilds of phytophagous insects may be unequally affected by natural enemies and foliage traits (Sipura 1999, Forkner and Hunter 2000, Denno et al. 2002, Moon and Stiling 2002). Furthermore, differences in herbivore load and actual damage levels on host plants can be crucial in mediating the strength of cascades across systems (Shurin et al. 2002, Mazía et al. 2009). To our knowledge, few experimental studies have tested the influence of top-down and bottom-up forces in contrasting habitats but on the same dominant plant species. Even fewer experiments have monitored responses to predators and plant resources of the same herbivore guilds in different sites within a system.

Natural variation in the relative magnitude of bottomup versus top-down forces may be also associated with plant responses to changing resource and herbivory levels (Hunter and Price 1992, Leibold et al. 1997). Plant species spanning broad habitat ranges, such as dominant trees in many temperate forests, usually exhibit large cross-site variation in foliar traits and growth rates, which may in turn influence the food web structure they support (Whitham et al. 2006). Patterns of resource use and allocation in plants vary with the prevalent type and level of abiotic stress they experience (Chapin et al. 1986), as well as with the need to defend from herbivorous consumers (Bazzaz et al. 1987, Herms and Mattson 1992). Thus, changes in plant growth and/or tissue quality resulting from altered nutrient availability may affect the transmission of trophic cascades, upward or downward (Leibold et al. 1997, Forkner and Hunter 2000, Boyer et al. 2003). Indeed, within a given habitat, top-down forces might be intensified by resource pulses only if these enhance host plant quality to herbivores (Stiling and Moon 2005).

In this study, we evaluate the direct and indirect shortterm effects of nutrient inputs and bird predation on tree growth, insect abundance and folivory rates, in two contrasting southern beech Nothofagus pumilio forests of northern Patagonia, Argentina. Previous work in this system showed that habitat type (dry vs wet) interacts with interannual climatic variation affecting the amount of top-down control on insect folivory (Mazía et al. 2004, 2009). Little is known about the role of soil nutrients and their possible interaction with insectivorous birds in controlling tree growth and herbivory in temperate Patagonian forests. We tested whether nutrient inputs at the base of the food web increase the strength of top-down effects from bird predation on insect herbivores and host tree growth. For two years, juvenile $N$. pumilio trees were subjected to a factorial combination of nutrient addition and bird exclusion in a 'dry/warm' and a 'wet/cold' forest site. We selected these forest sites to evaluate the potential for natural variation in top-down versus bottom-up control while keeping the host plant species unchanged. We expected differential trophic regulation because the 'dry/warm' forest has higher total folivory, greater prevalence of concealed insect guilds (Mazía et al. 2004) and better growth conditions for understorey saplings than the 'wet/cold' forest.

\section{Methods}

\section{Study system}

The study was conducted in two Nothofagus pumilio forest sites located at opposite ends of a west-to-east precipitation gradient in Nahuel Huapi National Park, northwestern Patagonia, Argentina. Nothofagus pumilio is a broad-leaf deciduous tree forming extensive monospecific stands (Veblen et al. 1996). At the latitude of study, the Andes create a major barrier to the westerlies, which results in a pronounced eastward rain shadow. Annual precipitation declines from $\sim 3000 \mathrm{~mm}$ near the continental divide to $\sim 800 \mathrm{~mm}$ on the eastern foothills of the Andes (Barros et al. 1983). The climate is characterised by cold and wet winters, and mild and dry summers. Most precipitation falls as rain and snow during autumn and winter (March to September), before the start of the growing season (October to April). Forest soils developed from volcanic ashes (Mazzarino et al. 1998).

The study sites were located $\sim 70 \mathrm{~km}$ apart at Paso Puyehue ('wet/cold forest') near the continental divide $\left(40^{\circ} 37^{\prime} \mathrm{S}, 71^{\circ} 50^{\prime} \mathrm{W} ; 1173\right.$ m.a.s.l.) and at Paso Córdoba ('dry/warm forest') on the eastern limit of $N$. pumilio distribution $\left(40^{\circ} 36^{\prime} \mathrm{S}, 71^{\circ} 05^{\prime} \mathrm{W} ; 1237\right.$ m.a.s.l.). In this system, wet/cold forest sites appear to provide less favourable conditions to tree saplings and folivorous insects than dry/warm forest sites. This is reflected by lower growth rates of saplings and reduced folivore activity on adult (Mazía et al. 2004) and juvenile trees in the wet forest. Existing differences in several biotic and abiotic variables may be responsible for such patterns. The two forests differ with regard to above-ground net primary production, which declines by $\sim 30 \%$ from wet to dry forests (Mazía et al. 2004). This is associated with a closed-canopy understorey and a higher density of adult trees in the wet forest, compared to an open-canopy understorey in the dry forest. Soil nutrient contents are lower in the wet (total Kjeldahl N: $27 \pm 2 \mathrm{~g} \mathrm{~kg}^{-1}$; BrayKurtz P: $8.9 \pm 1.3 \mathrm{mg} \mathrm{kg}^{-1}$; $\mathrm{pH}: 5.8 \pm 0.1$; means \pm SE, $\mathrm{n}=10)$ than in the dry (N: $31 \pm 2 \mathrm{~g} \mathrm{~kg}^{-1} ; \mathrm{P}: 29.2 \pm$ $3.7 \mathrm{mg} \mathrm{kg}{ }^{-1}$; $\left.\mathrm{pH}: 6.4 \pm 0.1\right)$ forest site. Tree foliage duration is about 6 weeks shorter in the wet forest, which also has lower $\left(\sim 2^{\circ} \mathrm{C}\right)$ mean temperatures than the dry forest (as measured by HOBO data loggers).

The two forest sites differ in the identity of the dominant folivore guilds, which comprise exophytic feeders (mainly chewers and skeletonizers) in wet forests and endophytic insects (leaf miners and tiers) in dry forests (Mazía et al. 2004). The most conspicuous folivores belong in the Lepidoptera (Geometridae, Noctuidae, Saturnidae, Heterobathmiidae), Coleoptera (Curculionidae), Hymenoptera 
(sawflies) and Homoptera (Psyllidae) (Gentili and Gentili 1988, McQuillan 1993). The commonest foliage gleaning birds in these forests are the thorn-tailed rayadito Aphrastura spinicauda (Furnaridae) and the white-crested elaenia Elaenia albiceps (Tyranidae). During winter (when $N$. pumilio leaves are absent), A. spinicauda decreases in abundance, whereas $E$. albiceps migrates north (BecerraSerial and Grigera 2005). Both are medium-sized species (body length: $15 \mathrm{~cm}$ ) and are widely distributed in Andean forests (Deferrari et al. 2001, Becerra-Serial and Grigera 2005, González-Gómez et al. 2006).

The experiments ran from November to April during the 2004-2005 and 2005-2006 growing seasons (hereafter 2005 and 2006, respectively). Mean annual temperatures were $9.1^{\circ} \mathrm{C}$ for 2005 and $8.8^{\circ} \mathrm{C}$ for 2006 (Bariloche airport station, ca $50 \mathrm{~km}$ south and $75 \mathrm{~km}$ southeast of Paso Córdoba and Paso Puyehue, respectively). Annual precipitation was $858 \mathrm{~mm}$ and $941 \mathrm{~mm}$, for 2005 and 2006, respectively, the second year being wetter than the previous 10 -year average $(860 \mathrm{~mm}, \mathrm{SD}=376 \mathrm{~mm})$.

\section{Experimental design}

In each forest, we haphazardly selected $35 \mathrm{~N}$. pumilio saplings averaging $4 \mathrm{~m}$ in height $(\mathrm{SD}=0.6 \mathrm{~m})$ and $6.4 \mathrm{~cm}$ in basal diameter $(\mathrm{SD}=1.4 \mathrm{~cm})$. Within a site, saplings were scattered over a 3-ha plot and were at least $5 \mathrm{~m}$ apart. On the basis of ring-width measures, saplings from the dry and wet forests were found to differ in their historical growth rates, and therefore corresponded to different age classes. Selected trees were, on average, 14-years old $(S D=4.9)$ and 52 -years old $(S D=16.6)$, in the dry and wet forest, respectively.

We performed two identically designed, factorial experiments, including two main treatments $(\mathrm{n}=7)$ : bird exclusion (with or without exclosure) and nutrient addition (with or without fertilizer). Birds were excluded by covering each individual tree with $4 \mathrm{~cm}^{2}$-mesh plastic netting. Exclosures were made of lightweight, green plastic netting to minimise physical interference on tree growth. Net exclosures produced little shading as they reduced light levels by less than 5\%. These nets allowed arthropods to move freely within and among trees, while effectively excluding foliagegleaning birds. To avoid excessive snow accumulation, net exclosures were removed at the end of the first season (May 2005) and replaced at the beginning of the next season (early November 2005). To control for exclosure effects, we added an open-net treatment ( $\mathrm{n}=7$ saplings), which allowed bird access to foliage while keeping the net on the tree top. All measured plant and insect variables did not significantly differ between open-net and control trees $(\mathrm{p}>0.1)$. For example, mean $( \pm S E)$ leaf area damage for open-net and control trees was $15.7 \%( \pm 1.9)$ and $16.4 \%( \pm 2.8)$ in the dry forest, and 7.8\% $( \pm 1.2)$ and $9.1 \%( \pm 1.2)$ in the wet forest, respectively. Also, mean relative growth rates (BAI ratio) for open-net and control trees was $1.6( \pm 0.2)$ and $2.0( \pm 0.3)$ in the dry forest, and $1.6( \pm 0.3)$ and $1.4( \pm 0.2)$ in the wet forest, respectively. Hence, these treatments were pooled, yielding 14 control (unfertilised, uncaged) trees. The nutrient treatment consisted of the addition of $750 \mathrm{~g} \mathrm{year}^{-1}$ of granulated, slow-release NPK fertiliser (N: 15.1\%, P: 6.6\%, $\mathrm{K}: 12.4 \%)$ to each designated tree; fertiliser was applied in three 250 -g doses distributed over the growing season.

\section{Plant and insect measurements}

At the end of each growing season, in April 2005 and 2006, we harvested four branches from each tree $(\sim 100$ leaves per branch) and recorded foliar damage by insects on a sample of 70 fully-expanded leaves per tree. Folivory rates were expressed as percentage of leaf area damaged by different feeding guilds, including leaf miners, tiers, skeletonisers and chewers. Leaf damage was measured by recording the area occupied by intact and damaged (or missing) tissue using a $1-\mathrm{mm}^{2}$ clear grid (Mazía et al. 2004). Damage caused by gall makers and pit feeders were expressed as number of galls or holes $\left(<1 \mathrm{~mm}^{2}\right)$ per leaf, respectively. Folivore abundance was estimated by counting all insects found in a foliage sample of $\sim 400$ leaves, and was expressed as the number of insects per 100 leaves per tree. This method is appropriate for common, less mobile insects (e.g. leaf miners and tiers), but it has limitations for estimating the abundance of mobile, exophytic feeders with low overall incidence. To account for possible seasonal effects we recorded insect damage and abundance in a non-destructive census at the onset of the second season (November 2005). We did not further measure insect abundances to avoid disturbing the saplings, and because visual counts on trees of this size were impractical. As damage patterns were adequately represented by the April 2006 data (late season), we only present results from the latter date (except for leaf miners abundance, which pupate in early January).

In each harvest date, we analysed several chemical and physical foliar traits relevant to herbivory and tree performance, including concentrations of nitrogen $(\mathrm{N})$, phosphorus $(\mathrm{P})$, potassium $(\mathrm{K})$ and total phenolics (except for the dry forest in 2005). We also measured mean leaf size, toughness, dry weight, and specific leaf area (SLA). For these measurements, we chose a random sub-sample of fully expanded, undamaged leaves from each tree. The percentage of young (immature) leaves in the samples was also used as a response variable. Leaf $\mathrm{N}$ content was determined by semi-micro Kjeldahl digestion. Leaf $\mathrm{P}$ and $\mathrm{K}$ concentrations were measured after humid acid $\left(\mathrm{HNO}_{3} /\right.$ $\mathrm{HClO}_{4}$ ) digestions through induced-plasma atomic emission spectrophotometry (ICP-AES). Total phenolics were determined using the method described in Folgarait and Davidson (1994), with concentrations expressed as mg of gallic acid per $\mathrm{g}$ of leaf dry weight. Leaf toughness (expressed as $\mathrm{g} \mathrm{mm}^{-2}$ ) was measured as the weight needed to punch a hole through the laminae using a $1.6 \mathrm{~mm}$ diameter steel rod.

Individual sapling growth was measured as annual basal area increments (BAI) estimated by ring-width analysis. At the end of the experiment, we cored each tree at the base level $(5-10 \mathrm{~cm}$ height), counted annual growth rings to the pith or inner ring (which enabled us to estimate sapling age), and measured ring width to the nearest $0.01 \mathrm{~mm}$ with a computer-compatible incremental measuring device (Stokes and Smiley 1968). Radial ringwidth series were then converted to annual BAI series. 
Here, sapling radial growth is represented as the ratio between the BAI measured for each study year (20052006) and the average BAI for the three years prior to the experiment (2002-2004). This procedure allowed us to adjust tree growth during the experiment by the physiological condition of each sapling at the start of the experiment.

\section{Statistical analyses}

Treatment effects on total folivore abundance, total leaf damage, and tree growth rates were evaluated separately for each forest site using generalised linear models implemented in the $\mathrm{R}$ software (<www.r-project.org/>). These models included three main factors: nutrient addition, bird exclusion and study year (each with two levels), and their interactions. Data were modelled using the identity-link function but with different error structures according with the response variable; significance was tested through analysis of deviance (Crawley 2007). Percent leaf damage data showed a right-skewed distribution due to the large number of low values or zeros and were analysed using a gamma error distribution (after adding 0.1 to each value). Insect abundances were analysed using a quasi-Poisson error distribution due to overdispersion (Crawley 2007). Tree growth rates (BAI ratio) were modelled assuming Gaussian errors.

To test for overall treatment effects on the multiple responses of folivore guilds and measured foliar traits, we performed non-parametric multivariate analysis of variance (npMANOVA, Anderson 2001, McArdle and Anderson 2001). In separate analyses, we evaluated effects of fertilisation, bird exclusion, forest site, and their corresponding interactions on folivore abundance (miners, tiers and pit feeders), leaf damage (by miners, skeletonizers, tiers and pit feeders), and foliar traits (nine variables listed in Table 2). These analyses were performed only for 2006 because of low insect abundances in the wet forest for 2005 (Appendix 1 Table A1, A2). Non-parametric MANOVA revealed strong forest site and site $\times$ treatment effects on folivores and plant traits. Hence, responses of individual feeding guilds and leaf traits were then examined for each forest site using generalised linear models (including both study years). For different folivore guilds, leaf damage and abundance patterns were analysed assuming gamma and quasi-Poisson errors, respectively. Most leaf traits were modelled with Gaussian errors, except the percentage of young leaves and total phenolics in the wet forest (gamma errors). Lastly, because the age of experimental trees differed greatly between sites, we evaluated whether plant traits (averaged over two years) and leaf damage varied consistently with tree age for each separate site using simple correlation analysis.

To summarise patterns of treatment effects on this heterogeneous set of response variables, we calculated effect sizes for main factors and their interaction separately for each plant and insect response variable using the logresponse ratio (L) (Hedges et al. 1999, Borer et al. 2006, Gruner et al. 2008):

$\mathrm{L}_{\mathrm{N}}=\left[\ln \left(\overline{\mathrm{X}}_{\mathrm{NB}}\right)+\ln \left(\overline{\mathrm{X}}_{\mathrm{NC}}\right)\right]-\left[\ln \left(\overline{\mathrm{X}}_{\mathrm{CB}}\right)+\ln \left(\overline{\mathrm{X}}_{\mathrm{CC}}\right)\right]$
$\mathrm{L}_{\mathrm{B}}=\left[\ln \left(\overline{\mathrm{X}}_{\mathrm{NB}}\right)+\ln \left(\overline{\mathrm{X}}_{\mathrm{CB}}\right)\right]-\left[\ln \left(\overline{\mathrm{X}}_{\mathrm{NC}}\right)+\ln \left(\overline{\mathrm{X}}_{\mathrm{CC}}\right)\right]$

$\mathrm{L}_{\mathrm{I}}=\left[\ln \left(\overline{\mathrm{X}}_{\mathrm{CC}}\right)+\ln \left(\overline{\mathrm{X}}_{\mathrm{NB}}\right)\right]-\left[\ln \left(\overline{\mathrm{X}}_{\mathrm{NC}}\right)+\ln \left(\overline{\mathrm{X}}_{\mathrm{CB}}\right)\right]$

where $\overline{\mathrm{X}}$ represents the mean of each treatment: control (CC), nutrient addition (NC), bird exclusion (CB), and nutrient addition plus bird exclusion (NB). Thus, for nutrient effects $\left(\mathrm{L}_{\mathrm{N}}\right)$, positive values indicate that nutrient addition increased the response variable; for predation effects $\left(L_{B}\right)$, however, a positive value indicates that bird exclusion elicited a positive response. This allows one to interpret positive interactive effects as resulting from the synergistic interaction of nutrient addition and predator exclusion, e.g. for herbivore damage (Gruner et al. 2008). Note that since main effect magnitudes $\left(\mathrm{L}_{N}\right.$ and $\left.\mathrm{L}_{\mathrm{B}}\right)$ are calculated by summing the log average of two treatments, effects are approximately twice those calculated from simple $\log$ ratios (e.g. $\ln \left(\overline{\mathrm{X}}_{\mathrm{NC}} / \overline{\mathrm{X}}_{\mathrm{CC}}\right)$; Borer et al. 2006). Effects were calculated separately for each study site and year but, for brevity, results are shown only for 2006 (qualitative patterns were essentially the same for 2005). The logresponse ratio allowed us to graphically show the magnitude of the treatment effects for each response variable, independently of the actual value of the mean and its error distribution (gamma, Gaussian or Poisson). Effect sizes thus facilitated comparisons between the magnitudes of bottomup and top-down forces at different levels of the food web.

\section{Results}

\section{Overview of bottom-up and top-down effects}

Tree growth rates, total leaf damage and total folivore abundance for control plants (unfertilised, uncaged) were all higher in dry than in wet forest saplings (Fig. 1). Mean ( \pm SE) leaf area damage on control trees was $14.8 \%( \pm 1.4)$ and $6.1 \%( \pm 0.7)$ in the dry and wet forests, respectively. Interannual changes in herbivory and tree growth were apparent in both forests (Appendix 1 Table A1, A2) but, for the most part, did not significantly influence responses to either nutrient addition or bird exclusion (treatment $\times$ year effects $\mathrm{p}>0.1$; Table 1,2 ). In the wet forest, total folivore abundance and leaf damage increased by 10 -fold and 2-fold, between 2005 and 2006, respectively (Table 1, Appendix 1 Table A2).

Irrespective of forest site and year of study, nutrient addition and bird exclusion did not significantly interact in affecting tree growth, total leaf damage and overall folivore abundance (Fig. 1, Table 1,2). However, the observed effects of fertiliser and birds varied between sites. In the dry forest, nutrient addition increased radial tree growth, leaf damage frequency and total folivore abundance (Fig. 1, Table 1,2). The percent leaf area damaged by insects was also higher on fertilised trees but this effect was not significant (Table 1). On the other hand, bird exclusion significantly increased total damage frequency and leaf area damaged, and also reduced radial growth in dry forest trees (Fig. 1). Total folivore abundance was, on average, higher in caged than in control saplings but this difference was not significant (Table 1). In the wet forest, by contrast, nutrient addition only enhanced folivore abundance (Table 1, Fig. 1) especially in 2006 (Appendix 1 Table A2). Bird exclusion had no significant effects on 

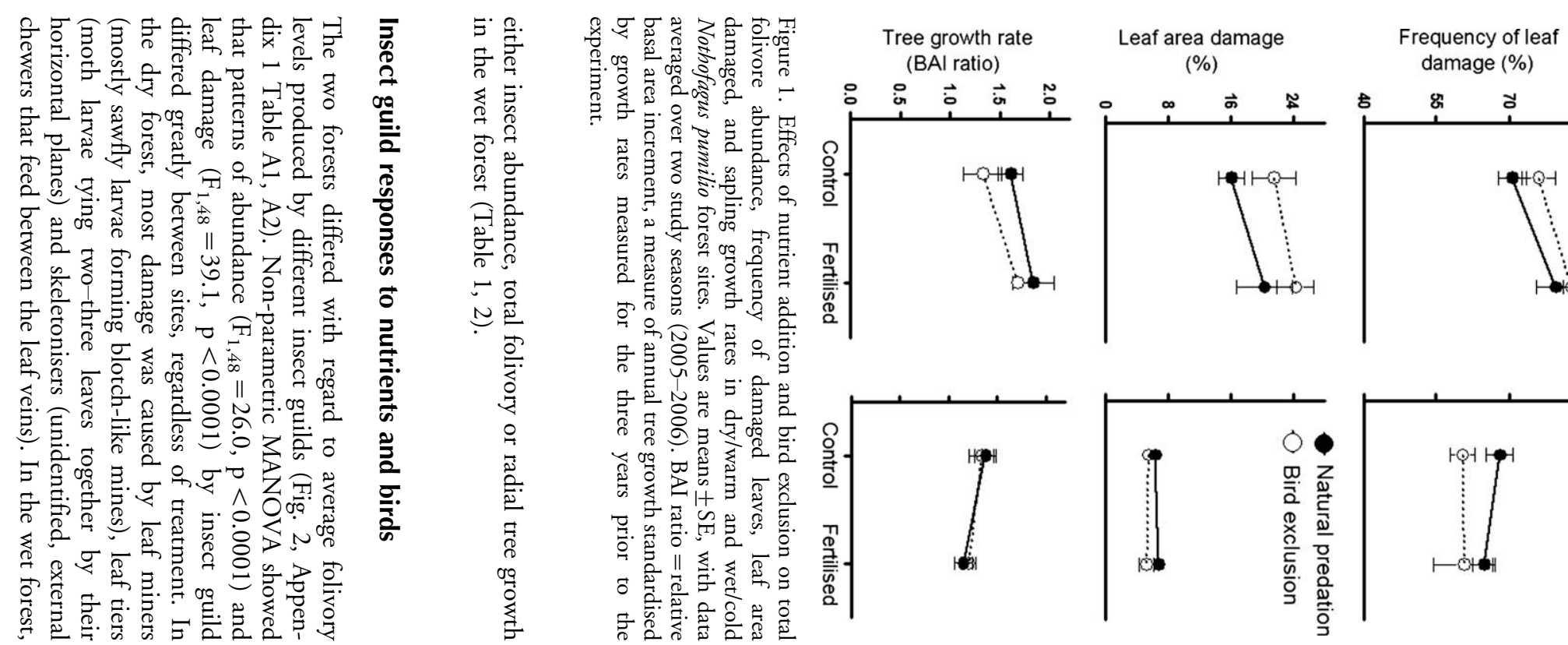

Folivore abundance (no./ 100 leaves)
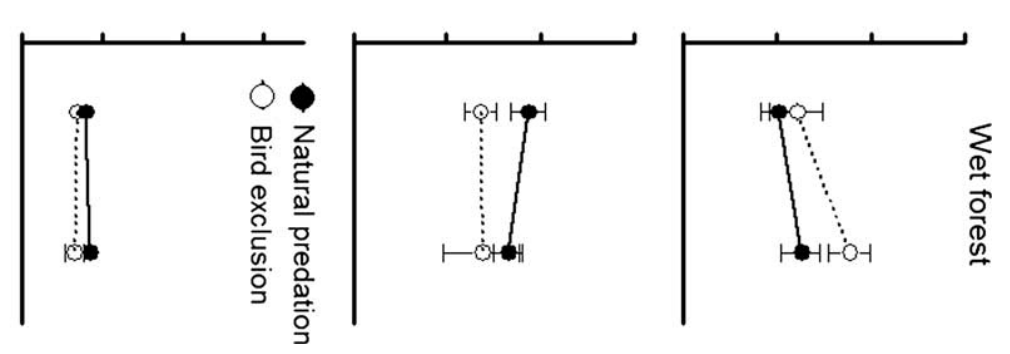

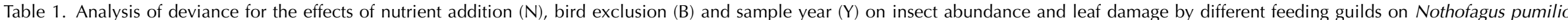
saplings in dry and wet forest sites of northern Patagonia.

\begin{tabular}{|c|c|c|c|c|c|c|c|c|c|c|c|c|}
\hline & \multicolumn{6}{|c|}{ Dry forest } & \multicolumn{6}{|c|}{ Wet forest } \\
\hline & Nutrients & Birds & Year & $\mathrm{N} \times \mathrm{B}$ & $N \times Y$ & $B \times Y$ & Nutrients & Birds & Year & $\mathrm{N} \times \mathrm{B}$ & $N \times Y$ & $\mathrm{~B} \times \mathrm{Y}$ \\
\hline \multicolumn{13}{|l|}{ Abundance } \\
\hline Total & $10.2^{* *}$ & 1.0 & 2.9 & 0.1 & 3.9 & 1.5 & 4.9* & 2.5 & $140.0^{* * *}$ & 0.1 & 4.8* & 0.7 \\
\hline leaf miners & 8.0** & $<0.1$ & $\mathrm{n} / \mathrm{a}$ & 0.3 & $\mathrm{n} / \mathrm{a}$ & $\mathrm{n} / \mathrm{a}$ & 3.5 & 0.5 & $\mathrm{n} / \mathrm{a}$ & 1.3 & $\mathrm{n} / \mathrm{a}$ & $\mathrm{n} / \mathrm{a}$ \\
\hline leaf tiers & $7.0^{*}$ & $5.0^{*}$ & $40.1^{* * *}$ & 2.1 & 0.2 & 1.8 & N/a & $\mathrm{n} / \mathrm{a}$ & $\mathrm{n} / \mathrm{a}$ & $\mathrm{n} / \mathrm{a}$ & $\mathrm{n} / \mathrm{a}$ & $\mathrm{n} / \mathrm{a}$ \\
\hline pit feeders & $\mathrm{n} / \mathrm{a}$ & $\mathrm{n} / \mathrm{a}$ & $\mathrm{n} / \mathrm{a}$ & $\mathrm{n} / \mathrm{a}$ & $\mathrm{n} / \mathrm{a}$ & $\mathrm{n} / \mathrm{a}$ & 1.2 & 1.1 & $\mathrm{n} / \mathrm{a}$ & $<0.1$ & $\mathrm{n} / \mathrm{a}$ & $\mathrm{n} / \mathrm{a}$ \\
\hline Damage frequency & $8.3^{* *}$ & $4.3^{*}$ & $51.5^{* * *}$ & 0.1 & 0.1 & 0.8 & 0.7 & 3.2 & $23.1^{* * *}$ & 0.3 & $<0.1$ & 0.3 \\
\hline \multicolumn{13}{|l|}{ Leaf area damage } \\
\hline total & 2.9 & $11.6^{* *}$ & $<0.1$ & 1.7 & $<0.1$ & 0.8 & $<0.1$ & 3.5 & $52.2^{* * *}$ & 0.3 & 0.1 & $<0.1$ \\
\hline leaf miners & 0.4 & 4.8* & $13.3^{* * *}$ & $5.8^{*}$ & 0.5 & 0.1 & $10.4^{* *}$ & 0.1 & $25.6^{* * *}$ & 5.4* & 1.1 & 3.3 \\
\hline skeletonizers & $5.6^{*}$ & $4.7^{*}$ & $<0.1$ & $<0.1$ & 0.8 & 1.0 & 0.2 & $4.0^{*}$ & $226.0 * * *$ & $<0.1$ & 0.3 & 2.1 \\
\hline leaf tiers & $7.0^{*}$ & $5.7^{*}$ & 0.6 & 0.5 & 0.1 & $4.6^{*}$ & N/a & $\mathrm{n} / \mathrm{a}$ & $\mathrm{n} / \mathrm{a}$ & $\mathrm{n} / \mathrm{a}$ & $\mathrm{n} / \mathrm{a}$ & $\mathrm{n} / \mathrm{a}$ \\
\hline pit feeders & 1.7 & $<0.1$ & $7.9 * *$ & $<0.1$ & 0.5 & 0.2 & 1.4 & $24.5^{* * *}$ & $76.3^{* * *}$ & 2.4 & 0.5 & $7.9 * *$ \\
\hline
\end{tabular}

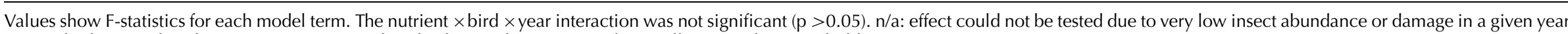
or site (leaf miner abundance was not measured in the first study year). Significant effects are shown in bold: ${ }^{* * *} p<0.001,{ }^{* *} p<.01,{ }^{*} p<0.05$ 

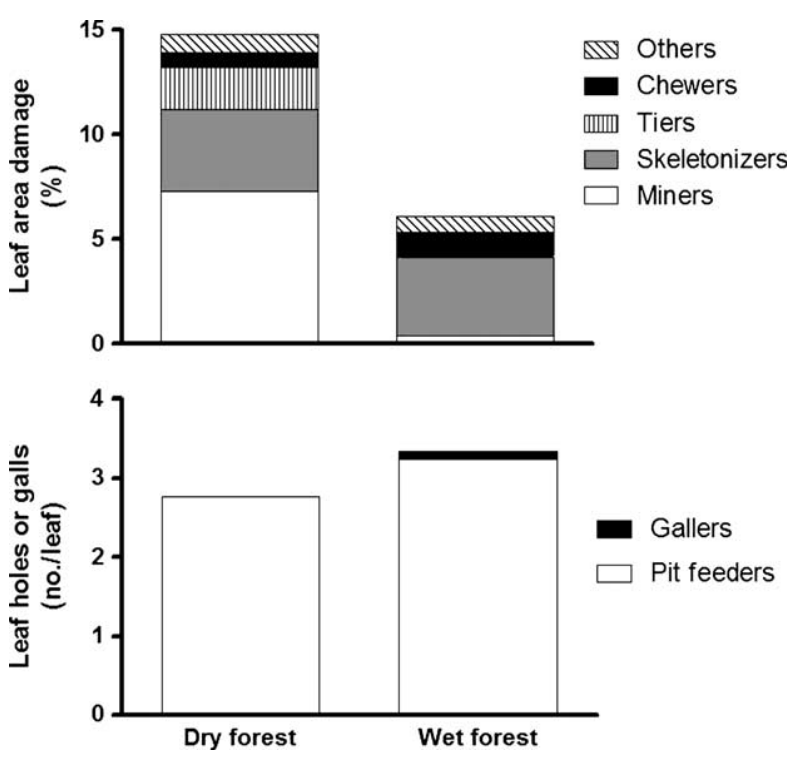

Figure 2. Leaf damage levels by different insect feeding guilds on Nothofagus pumilio saplings in dry and wet forest sites of northern Patagonia. Data shown are average values for control trees (unfertilised, without bird exclosures) in 2005 and 2006.

most damage was caused by skeletonisers; phloem suckers (pit feeders, gall makers) were more common than in dry forest trees, while leaf miners and tiers were almost absent (Fig. 2).

Nutrient addition exerted significant positive effects on folivore guild abundances in both forest sites (npMANOVA: $\mathrm{F}_{1,48}=3.8, \mathrm{p}=0.014$; fertiliser $\times$ site $\mathrm{F}_{1,48}=2.7$, $\mathrm{p}=0.052$ ), whereas bird exclusion did not affect insect abundances ( $p$-values $>0.1$ ). Bird exclusion affected patterns of leaf damage by folivore guilds (npMANOVA: exclosure $\times$ site $\mathrm{F}_{1,48}=3.7, \mathrm{p}=0.022$ ). Importantly, however, we did not find a significant interaction between nutrient addition and bird exclusion on folivore abundances $\left(\mathrm{F}_{1,48}=1.3, \mathrm{p}=0.3\right)$ or leaf damage patterns $\left(\mathrm{F}_{1,48}=\right.$ $0.1, \mathrm{p}=0.9)$, and this was irrespective of forest site (npMANOVAs: fertiliser $\times$ exclosure $\times$ site $\mathrm{p}>0.1$ ). We also found little statistical evidence for an interaction between nutrient and bird effects when analyses were conducted separately for each site and for individual feeding guilds (Table 1). The only exception was the amount of damage by mining insects $(\mathrm{p}<0.05$, Fig. $3 \mathrm{~b}, 4 \mathrm{~b})$. Nutrient addition increased leaf miner damage for uncaged trees, whereas bird exclusion tended to enhance it for unfertilised trees (Appendix 1 Table A1).

Within each forest, both fertilisation and bird exclusion had significant, albeit heterogeneous effects on insect abundance and damage rates among folivore guilds (Table 1, Fig. 3, 4). In the dry forest, the direction of treatment effects was consistent across folivore guilds. Nutrient addition effects on insect abundance or leaf damage were generally larger $\left(\mathrm{L}_{\mathrm{N}} \sim 0.5-1.5\right)$ than bird exclusion effects (all $\mathrm{L}_{B}<0.6$, Fig. 3a-b). Fertiliser addition increased abundance of two dominant guilds, leaf miners and tiers, and also enhanced foliar damage by leaf tiers (mostly in 2006) and skeletonisers (Fig. 3a-b, Table 1, Appendix 1 Table A1). On the other hand, bird exclusion increased leaf tier abundance, and foliar damage by tiers (only 2005) and skeletonisers (Fig. 3a-b). In the 
(a) Folivore abundance
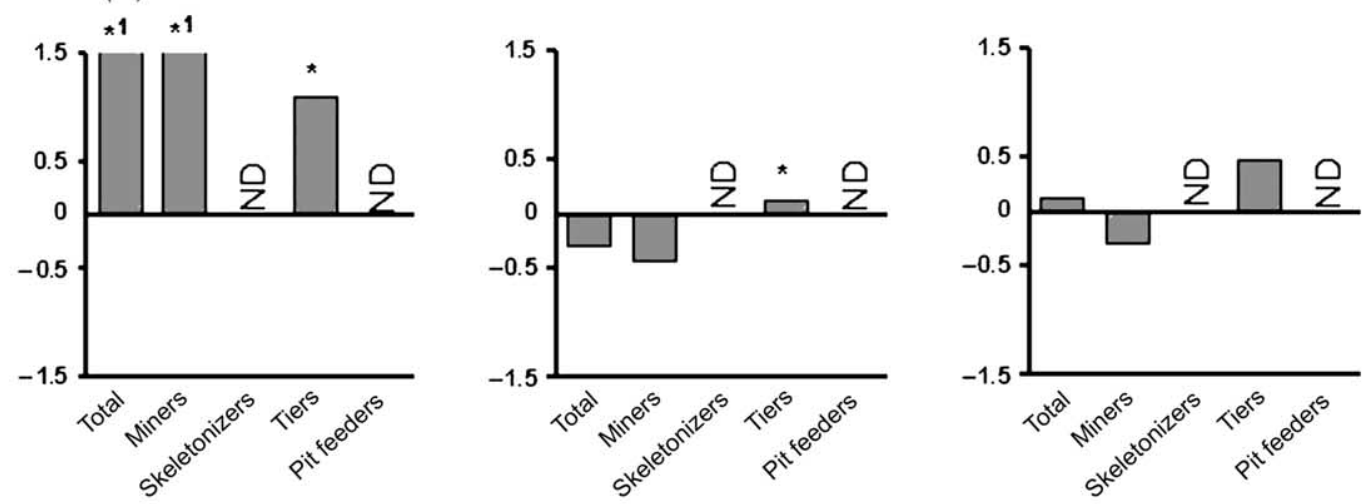

(b) Leaf damage
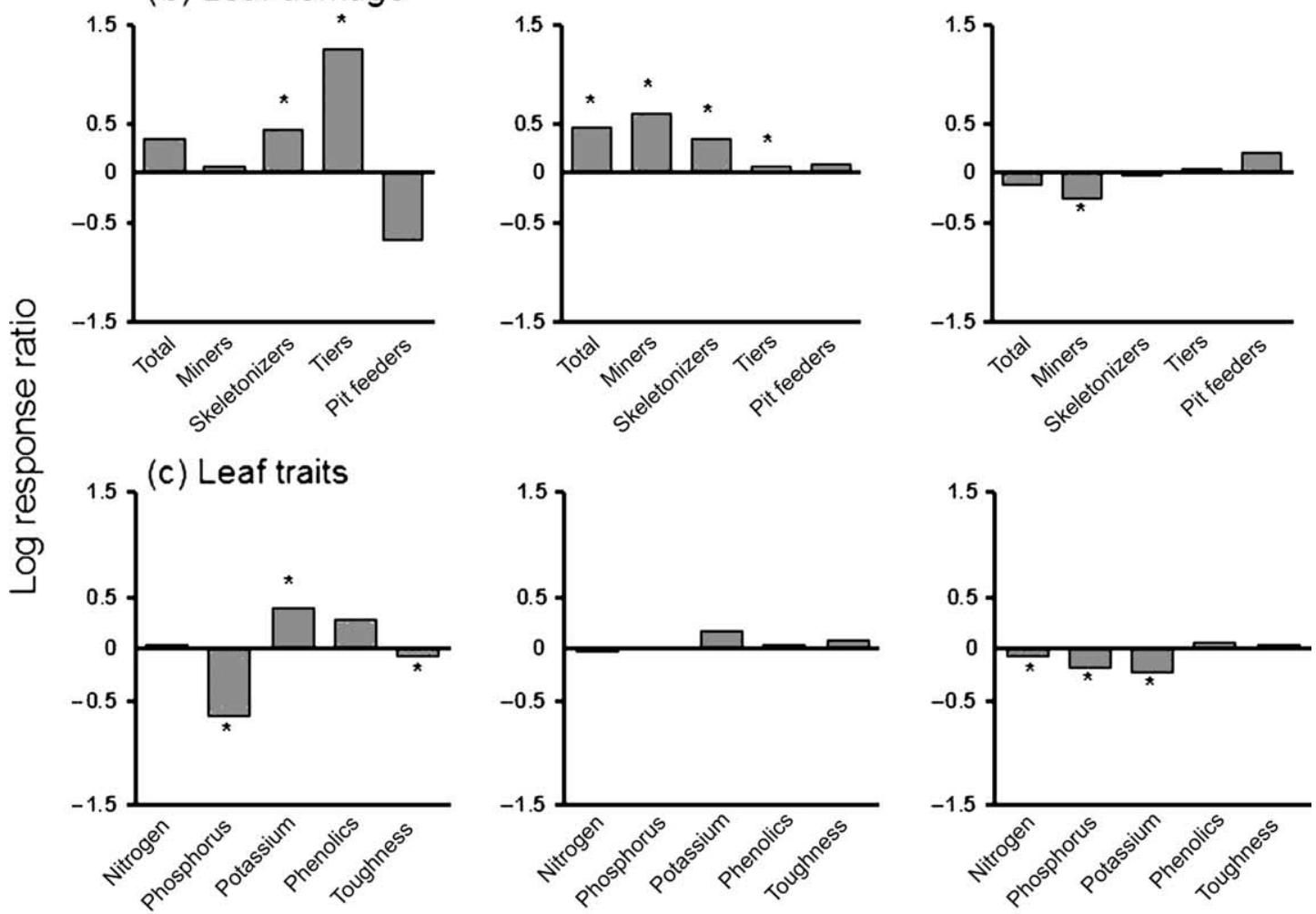

(d) Tree growth
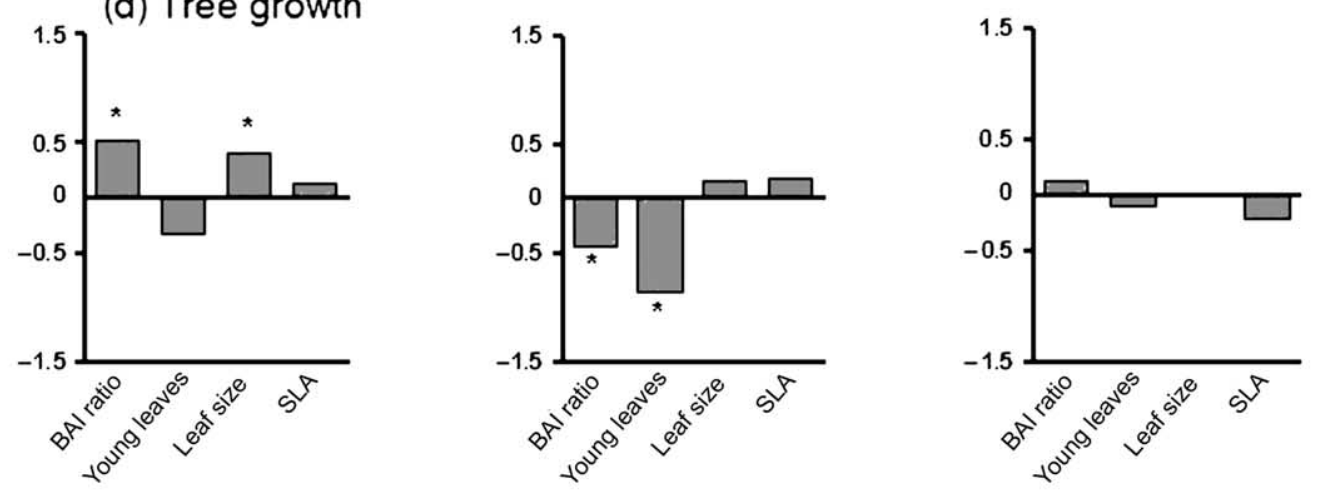

Nutrient addition

Bird exclusion

\section{Interaction}

Figure 3. Effect sizes (log response ratio) for nutrient addition, bird exclusion, and their interaction on insect folivore abundance, leaf damage rates and plant traits for Nothofagus pumilio saplings in the dry forest. Results shown are for the second year of experiment (2006). Asterisks above bars indicate significant treatment effects from analysis of deviance (Table 1,2). ${ }^{1}$ Effect size for total and leaf miner abundance was 2.0 and 3.3 , respectively $\mathrm{ND}=$ no data available. 
(a) Folivore abundance
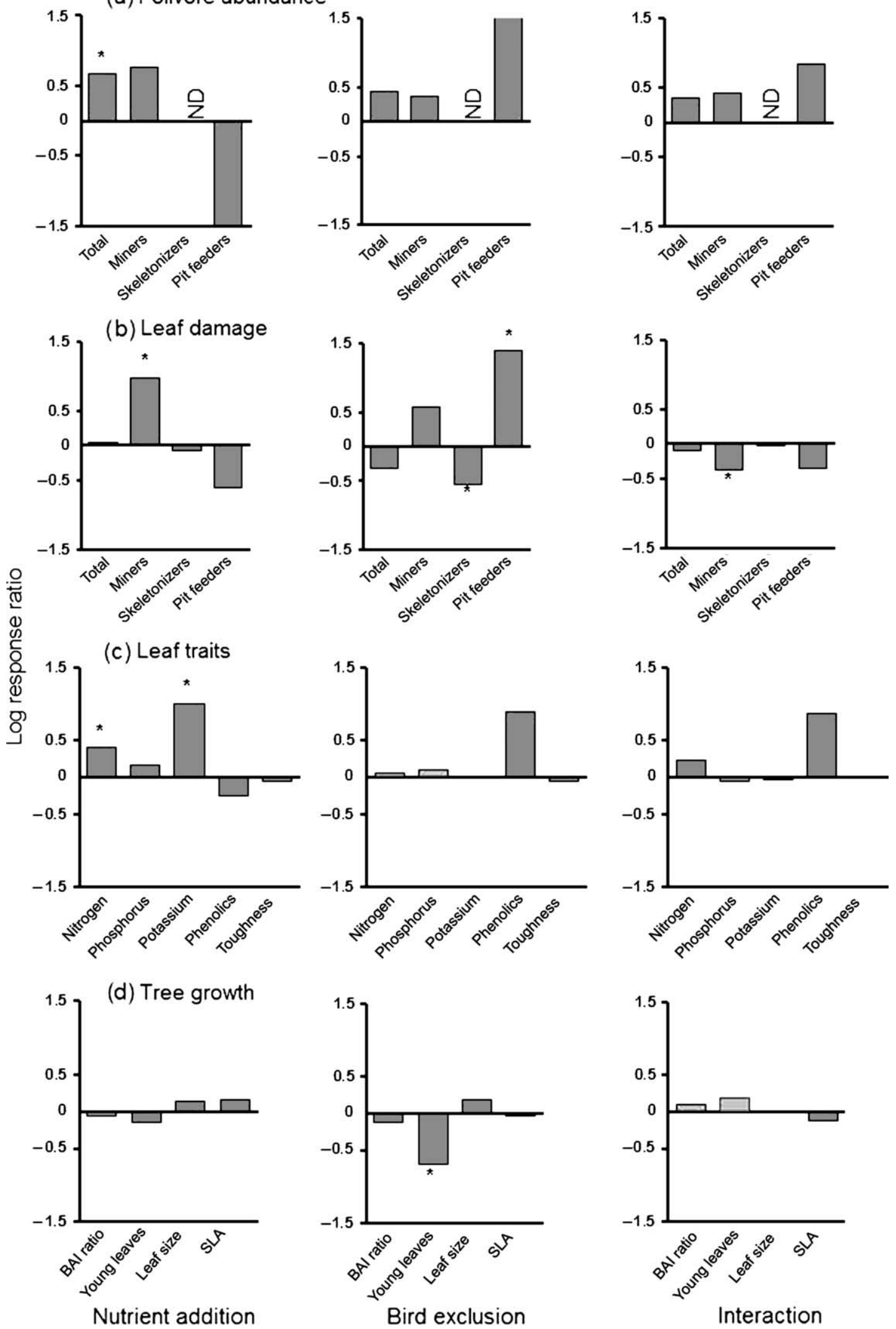

Figure 4. Effect sizes (log response ratio) for nutrient addition, bird exclusion, and their interaction on insect folivore abundance, leaf damage rates and plant traits for Nothofagus pumilio saplings in the wet forest. Results are for the second year of experiment (2006). Asterisks above bars indicate significant treatment effects from analysis of deviance (Table 1, 2). ${ }^{1}$ Effect size for pit feeder abundance was -1.9 and 1.6 for nutrient addition and bird exclusion, respectively. ND = no data available. 
wet forest, treatments had few significant, and largely opposite effects on the dominant folivore guilds (Table 1, Fig. 4a-b). Bird exclusion increased leaf damage by pit feeders, especially in $2006\left(\mathrm{~L}_{\mathrm{B}}=1.4\right)$ but lowered damage by leaf skeletonisers $\left(\mathrm{L}_{\mathrm{B}}=-0.5\right.$; Appendix 1 Table A2).

\section{Treatment effects on foliar traits}

Non-parametric MANOVA indicated that the dry and wet forest sites differed greatly with regard to $N$. pumilio sapling traits $\left(\mathrm{F}_{1,48}=24.7, \mathrm{p}<0.0001\right)$. Moreover, overall effects of nutrient addition on leaf traits varied significantly between sites (npMANOVA: fertiliser $\mathrm{F}_{1,48}=9.8$, $p=0.0001$, fertiliser $\times$ site $F_{1,48}=5.3, p=0.004$ ), whereas bird exclusion effects did not (exclosure $\mathrm{F}_{1,48}=6.5, \mathrm{p}=$ 0.001 , exclosure $\times$ site $p>0.9$ ). There was no significant overall interaction between effects of nutrient addition and bird exclusion on plant traits (npMANOVA: $\mathrm{F}_{1,48}=$ $1.1, \mathrm{p}=0.4)$. When analyses were conducted for each separate forest, we found several significant treatment effects on structural and chemical leaf traits in both sites (Table 2, Fig. 3, 4).

In the dry forest, interannual differences in foliar traits did not modify the effects of treatments (Table 2). Nutrient addition increased leaf size (only in 2006) and reduced tissue toughness (Fig. 3c-d). Fertiliser effects on foliar chemistry, however, depended on the bird exclusion treatment (interactions $\mathrm{p}<0.05$, Table 2, Fig. 3c). Fertilisation increased leaf $\mathrm{N}$ and $\mathrm{K}$ concentrations in uncaged trees, and decreased leaf P mainly in caged trees (Appendix 1 Table A1). Conversely, in unfertilised saplings, foliar nutrients $(\mathrm{N}, \mathrm{P}, \mathrm{K})$ were higher under bird exclusion (Appendix 1 Table A1). Neither fertilisation nor bird exclusion altered total leaf phenolics in dry forest trees (Table 1, Fig. 3c). Lastly, bird exclusion strongly reduced the percentage of newly expanded (young) leaves in 2006 (Fig. 3d, Appendix 1 Table A1).

In the wet forest, treatment effects on foliar traits were often conditional on the study year (treatment $\times$ year $p<0.05$ ), but there were no significant interactions between fertilisation and bird exclusion (Table 2). Fertiliser addition increased leaf $\mathrm{N}$ and $\mathrm{K}$ concentrations of wet forest trees in 2006 (Fig. 4c, Appendix 1 Table A2), and had opposite effects on leaf size between years (Appendix 1 Table A2). Bird exclusion reduced the percentage of young leaves (Table 2 , Fig. 4d), but did not affect other leaf traits (Table 2).

Regardless of treatment, in the dry forest, sapling age correlated negatively with radial growth rate (Pearson's $r=-0.4, p=0.038)$ and positively with leaf $P$ concentration $(r=0.4, p=0.018)$. In the wet forest, tree age only showed a negative correlation with leaf toughness $(r=-0.3, p=0.047)$. Importantly, we found no consistent relationship between sapling age and leaf damage levels in either forest site ( $r$ values $<0.2, p>0.4$ ).

\section{Discussion}

In this study we took advantage of the wide distribution of Nothofagus pumilio in northern Patagonia to manipulate nutrient inputs and bird access to the same host tree species in two contrasting forest sites. Overall, we found that nutrient supply did not affect the magnitude of predator effects on insect abundance, herbivory and tree growth. Likewise, nutrient effects on plants and insects were mostly independent of predator exclusion. Hence, there was no compelling evidence for an interaction between nutrient supply and bird predation within these forest communities.

Nevertheless, the strength of direct and indirect effects of nutrient supply and bird predation changed between forest sites. Treatment effects were generally weak in the wet forest, where sapling growth and folivory rates were low compared to the dry forest. This pattern suggests that factors other than nutrients or birds would control plant growth and folivory in the wet forest. In contrast, nutrient addition and bird exclusion strongly affected tree growth and insect folivores in the dry forest. Both theory and empirical data suggest that the relative roles of bottom-up versus top-down factors should vary with habitat productivity or stress (Oksanen et al. 1981, Leibold et al. 1997, Worm et al. 2002, Schädler et al. 2003). While we studied only two forest sites differing in several abiotic and biotic features, our results appear to be consistent with the view that the harsher environmental conditions of the wet forest may have constrained, directly or indirectly, the potential for downward and upward trophic cascades (Chase 1996, Ritchie 2000).

\section{Bottom-up effects on trees and folivores}

Nutrient enrichment had different effects on saplings depending on the forest site. In the dry forest, fertilisation increased tree radial growth during both study seasons and leaf size in 2006, while it reduced leaf toughness. In the wet forest, fertiliser addition did not affect tree growth but increased foliar $\mathrm{N}$ and $\mathrm{K}$ contents in 2006 (Table 2, Fig. 3, 4). We suggest that these response patterns might reflect alternative allocation strategies of saplings under different environmental conditions. The observed fertilisation effect on dry forest trees indicates their growth was limited by nutrient availability (Chapin et al. 1986, Boyer et al. 2003). In contrast, other factors such as light availability may be important in limiting growth of saplings established in the closed-canopy understorey of the wet forest. Indeed, for untreated plants, foliar nutrient contents were higher in wet forest trees (Appendix 1 Table A1, A2). Noteworthy, saplings in the wet forest while similar in size were, on average, 38 years older (Methods) and had lower radial growth rates (Appendix 1 Table A1, A2) than saplings in the dry forest. Such differences in tree ontogeny and tree growth may be important in mediating differential responses to nutrient addition between forest sites, which could also have consequences on folivory (Boege and Marquis 2005). However, we think it unlikely that differences in overall folivore activity between sites had been driven by sapling age. Firstly, we found no significant correlation between tree age and leaf damage in this study. Furthermore, Mazía et al. (2004) also recorded lower herbivory in wet versus dry forests for older/larger, adult $N$. pumilio trees.

Nutrients had a positive indirect influence on total folivore abundance in both forests but the effect magnitude 
was larger on dry forest trees, as densities of two major feeding guilds were enhanced by fertilisation (Fig. 3a, 4a). The latter indirect effect was reflected by the increased proportion of damaged leaves (Fig. 1) and leaf area damaged by leaf-tying and skeletonising insects (Fig. 3b). In the dry forest, propagation of a bottom-up cascade from nutrients to insects might have been mediated by the increased leaf size of fertilised trees, as detected during the second study season. Leaf size may be an important architectural trait to leaf-tying caterpillars that feed within leaf shelters constructed from closely overlapping leaves (Marquis et al. 2002). In addition, larger leaves may provide a better resource for leaf miners, attracting ovipositing females or enhancing larval survival on fertilised trees (Bultman and Faeth 1986, Kagata and Ohgushi 2002). Results for the wet forest, by contrast, suggest a folivore numerical response to fertilisation mediated by leaf nutrient quality (Fig. 4). In a recent meta-analysis of fertilisation-bypredator removal experiments, Borer et al. (2006) found that bottom-up effects of nutrients increased plant biomass but generally became attenuated as they propagated to upper trophic levels. Our results do not conform to this broad, multi-system pattern, perhaps because their metaanalysis included a small number of terrestrial studies, and just one in forests (Borer et al. 2006). However, our findings agree with those of forest studies that revealed bottom-up cascades from nutrient additions being transmitted to insect densities and/or folivory rates (Sipura 1999, Forkner and Hunter 2000, Gruner 2004, Cornelissen and Stiling 2006).

\section{Top-down effects on folivores and trees}

Several experiments demonstrated that birds can control insect density and leaf damage in forests (Holmes et al. 1979, Marquis and Whelan 1994, Sipura 1999, Forkner and Hunter 2000, Van Bael et al. 2003, 2008, Gruner 2004, Mazía et al. 2004). Yet predator impacts on folivores do not always translate into positive indirect effects on tree growth (Strong et al. 2000, Van Bael et al. 2008). Here, bird exclusion increased leaf damage and reduced sapling growth in a dry forest, but had little impact on insects or trees in a wet forest. In the dry forest, increases from 17 to $24 \%$ of leaf area loss to insects after bird exclusion were correlated with a $19 \%$ reduction in tree radial growth (Marquis and Whelan 1994, Sipura 1999). This reduced tree growth corresponded with the decreased production of young leaves under high folivory in the absence of birds (Fig. 3). Theory predicts that the strength of top-down cascades should increase as abiotic limitations to plant and herbivore biomass are relaxed (Oksanen et al. 1981, Leibold et al. 1997, Richards and Coley 2007). Our results support this prediction in that avian predators were a relevant force in a dry/warm forest with rapid sapling growth and elevated folivory rates. Forest birds may exert greater consumer pressure on stands with high prey availability (Jones et al. 2003, Richards and Coley 2007).

The absence of significant top-down effects in the wet forest was surprising in the light of recent work in the system. Mazía et al. (2009) found during a strong La Niña event that birds were more effective at reducing leaf-chewer herbivory in wet than in dry $N$. pumilio forest. However, the greater strength of top-down control in wet forest coincided with the episodic rise of folivory rates during the dry and warm conditions associated with ENSO (Mazía et al. 2009). Together, these studies fit the notion that strong and weak top-down cascades may temporally alternate in wet forest sites (Yang et al. 2008). Factors such as canopy shading, low temperatures, and a short growing season can be important determinants of insect herbivore activity (Ritchie 2000, Bale et al. 2002), thus contributing to limit the potential for strong carnivore indirect effects (Hunter and Price 1992, Polis 1999). Finally, it could be that the smaller effects of bird exclusion in the wet forest had reflected the influence of other carnivores (spiders, parasitoids) not controlled by our design. Yet the trophic importance of arthropod predators in these forests is not known.

\section{Interaction between top-down and bottom-up forces}

It has been suggested that top-down effects should be intensified by resource enrichment to plants (Abrams 1993, Forkner and Hunter 2000, Yang et al. 2008). Accordingly, we expected larger effects of bird exclusion on fertilised saplings. While fertilisation increased folivore abundance and folivory rates, it generally did not influence the impact of birds in either forest site. This finding adds to recent meta-analyses of nutrient versus consumer regulation of trophic structure (Borer et al. 2006, Gruner et al. 2008), in which evidence for a statistical interaction between bottomup and top-down forces was found to be limited. This lack of interdependence might have different interpretations depending on the forest site. In the wet forest, insect abundances and damage levels seemed too low as to elicit any substantial effect from bird exclusion, even after fertilisation (Shurin et al. 2002). On the other hand, in the dry forest, insectivorous birds were apparently unable to respond to increased folivore abundance on fertilised trees. At the local scale of experiment, synergistic interactions between bottom-up and top-down forces require a functional or aggregative numerical response of carnivores to enhanced prey availability (Forkner and Hunter 2000, Moran and Scheidler 2002, Yang et al. 2008). Our results suggest that bird predation on fertilised saplings did not conform to such behavioral response patterns.

The only exception was the interactive effect of nutrients and birds on leaf damage by mining insects (Fig. 3, 4). Yet, against theoretical expectations (but see Williams 1999), the observed bottom-up top-down interaction was antagonistic; top-down reductions of leaf-miner damage were most apparent in unfertilised, not in fertilised, trees. Amongst the few experiments focusing on tri-trophic systems with trees, insect herbivores and their vertebrate predators, two studies reported carnivore effects that were conditional on plant nutrient status (Sipura 1999, Forkner and Hunter 2000), while the other found no interaction at all (Gruner 2004). In these studies nutrient-by-predator interactions varied from synergistic to antagonistic. Forkner and Hunter (2000) showed that top-down effects on phloem feeders of oak saplings increased in strength with fertilisation, whereas Sipura (1999) found that bird-induced reductions 
of leaf-chewer abundance and folivory on a willow species were greater on unfertilised trees. Clearly, more experiments will be needed before we fully understand how soil resources and natural enemies interact in controlling plant-herbivore interactions in forest communities.

\section{Relative strength of bottom-up versus top-down indirect effects}

Early controversy about the preeminence of bottom-up or top-down forces has given way to the more enlightening question of what makes their relative strengths vary within and among systems (Hunter and Price 1992, Worm et al. 2002, Borer et al. 2006). In our system, indirect effects from nutrient input and bird removal were important in the dry forest, as they propagated through the trophic web affecting species beyond the adjacent trophic level. However, nutrients had stronger effects than birds on insect densities and folivory rates $\left(\mathrm{L}_{\mathrm{N}} \sim 0.5-1.5\right.$ whereas all $\mathrm{L}_{\mathrm{B}}<$ 0.6 , Fig. 3a-b), while bird predation had a similarly positive impact as nutrients on tree radial growth (Fig. $3 \mathrm{~d}$ ). In the wet forest, trees and insect herbivores were barely affected by bottom-up or top-down manipulations, although fertilisation had more significant effects than bird exclusion (Table 1,2). Overall, these patterns suggest that bottom-up effects induced by nutrient supply may exert a greater influence on tree-folivore interactions than top-down impacts from insectivorous birds. This conclusion is in agreement with other forest studies in which nutrient resources cascaded up to alter arthropod communities but the reversed trophic cascade did not always materialise (Sipura 1999, Forkner and Hunter 2000, Gruner 2004, Cornelissen and Stiling 2006). It thus appears that current evidence from tree-based webs does not fit well the notion of an asymmetrical, top-down control of trophic dynamics as revealed by recent meta-analyses dominated by aquatic systems (Borer et al. 2006: Table 3).

It has been proposed that feeding-guild heterogeneity may prevent the transmission of trophic cascades (Hunter and Price 1992, Abrams 1993, Gruner 2004). Only a few studies have looked at the variability of responses to nutrient inputs or predator removals for insect herbivore guilds sharing a host plant (Forkner and Hunter 2000, Denno et al. 2002, Moon and Stiling 2002, Mazía et al. 2004). Although we found some variation in the magnitude and direction of folivore guild responses in both forests (see effect sizes in Fig. 3a-b, Fig. 4a-b), this heterogeneity did not appear to correlate with an overall attenuation of topdown or bottom-up effects (Gruner 2004). Instead, consistent damage responses among dominant feeding guilds likely contributed to propagate bird exclusion effects down to trees in the dry forest (Fig. 3). The opposing responses to bird exclusion of pit feeders and skeletonisers in the wet forest were probably inconsequential, given the low abundances and damage levels recorded there (Fig. 4).

In conclusion, our study provides novel empirical evidence for the simultaneous role of top-down and bottom-up forces in forest ecosystems. We have shown for two contrasting forests that soil nutrients and bird predation affected tree growth and insect folivores in an additive fashion, at least within the two-year time-frame of this study. Nevertheless, the strength of top-down and bottom-up cascades did vary geographically, between forest sites dominated by the same tree species.

Acknowledgements - We are very grateful to Cecilia Carrea, Claudio Ziperovich, Juan Gowda, Juan Karlanian, Marina Arbetman, Mariana Dondo, Melisa Blackhall, Noelia Barrios, Raúl Garibaldi and Soledad Díaz for their help at various stages of this project. Jennifer Rudgers made helpful comments on earlier drafts of the manuscript. This study was funded by Agencia Nacional de Promoción Científica y Tecnológica (BID OC-AR 1728 PICT Redes 331/1). Lucas Garibaldi was supported by a CONICET doctoral fellowship.

\section{References}

Anderson, M. J. 2001. A new method for non-parametric multivariate analysis of variance. - Aust. Ecol. 26: 32-46.

Abrams, P. A. 1993. Effect of increased productivity on the abundances of trophic levels. - Am. Nat. 141: 351-371.

Albarracín, M. T. and Stiling, P. 2006. Bottom-up and top-down effects on insect herbivores do not vary among sites of different salinity. - Ecology 87: 2673-2679.

Bale, J. et al. 2002. Herbivory in global climate change research: direct effects of rising temperature on insect herbivores. - Global Change Biol. 8: 1-16.

Barros, V. et al. 1983. Cartas de precipitación de la zona oeste de las provincias de Río Negro y Neuquén. - Internal Report, Fac. de Ciencias Agrarias, Univ. Nacional del Comahue, Neuquén, Argentina.

Bazzaz, F. A. et al. 1987. Allocating resources to reproduction and defense. - Bioscience 37: 58-67.

Becerra-Serial, R. M. and Grigera, D. 2005. Dinámica estacional del ensamble de aves de un bosque norpatagónico de lenga (Nothofagus pumilio) y su relación con la disponibilidad de sustratos de alimentación. - Hornero 20: 131-139.

Boege, K. and Marquis, R. J. 2005. Facing herbivory as you grow up: the ontogeny of resistance in plants. - Trends Ecol. Evol. 20: 441-448.

Borer, E. T. et al. 2005. What determines the strength of a trophic cascade? - Ecology 86: 528-537.

Borer, E. T. et al. 2006. Asymmetry in community regulation: effects of predators and productivity. - Ecology 87: 28132820.

Boyer, A. G. et al. 2003. Seasonal variation in top-down and bottom-up processes in a grassland arthropod community. - Oecologia 136: 309-316.

Bultman, T. L. and Faeth, S. H. 1986. Effect of within-leaf density and leaf size on pupal weight of a leaf-miner, Cameraria (Lepidoptera: Gracillariidae). - Southwest. Nat. 31: 201-206.

Chapin, F. S. III et al. 1986. The nature of resource limitation in plant communities. - Am. Nat. 127: 48-58.

Chase, J. M. 1996. Abiotic controls of trophic cascades in a simple grassland food chain. - Oikos 77: 495-506.

Cornelissen, T. and Stiling, P. 2006. Responses of different herbivore guilds to nutrient addition and natural enemy exclusion. - Ecoscience 13: 66-74.

Crawley, M. J. 2007. The R book. - Wiley.

Deferrari, G. et al. 2001. Changes in Nothofagus pumilio forest biodiversity during the forest management cycle. 2. Birds. - Biodiv. Conserv. 10: 2093-2108.

Denno, R. F. et al. 2002. Bottom-up forces mediate naturalenemy impact in a phytophagous insect community. - Ecology 83: $1443-1458$. 
Folgarait, P. J. and Davidson, D. W. 1994. Antiherbivore defenses of myrmecophytic Cecropia under different light regimes. - Oikos 71: 305-320.

Forkner, R. E. and Hunter, M. D. 2000. What goes up must come down? Nutrient addition and predation pressure on oak herbivores. - Ecology 81: 1588-1600.

Gentili, M. and Gentili, P. 1988. Lista comentada de los insectos asociados a las especies sudamericanas del género Nothofagus. - Monogr. Acad. Nac. Cs. Ex. Fis. y Nat. 4: 85-106.

González-Gómez, P. L. et al. 2006. Strengthened insectivory in a temperate forest fragment. - Oecologia 148: 137-143.

Gratton, C. and Denno, R. F. 2003. Inter-year carryover effects of a nutrient pulse on Spartina plants, herbivores, and natural enemies. - Ecology 84: 2692-2707.

Gripenberg, S. and Roslin, T. 2007. Up or down in space? Uniting the bottom-up versus top-down paradigm and spatial ecology. - Oikos 116: 181-188.

Gruner, D. S. 2004. Attenuation of top-down and bottom-up forces in a complex terrestrial community. - Ecology 85: 3010-3022.

Gruner, D. S. et al. 2008. A cross-system synthesis of consumer and nutrient resource control on producer biomass. - Ecol. Lett. 11: 740-755.

Halaj, J. and Wise, D. H. 2001. Terrestrial trophic cascades: how much do the trickle? - Am. Nat. 157: 262-281.

Hedges, L. V. et al. 1999. The metaanalysis of response ratios in experimental ecology. - Ecology 80: 1150-1156.

Herms, D. A. and Mattson, W. J. 1992. The dilemma of plants: to grow or defend. - Q. Rev. Biol. 67: 283-335.

Holmes, R. T. et al. 1979. Bird predation on forest insects: an exclosure experiment. - Science 206: 462-463.

Hunter, M. D. and Price, P. W. 1992. Playing chutes and ladders: heterogeneity and the relative roles of bottom-up and topdown forces in natural communities. - Ecology 73: 724-732.

Jones, J. et al. 2003. Climate and food synchronize regional forest bird abundances. - Ecology 84: 3024-3032.

Kagata, H. and Ohgushi, T. 2002. Clutch size adjustment of a leaf-mining moth (Lyonetiidae: Lepidoptera) in response to resource availability. - Ann. Entomol. Soc. Am. 95: 213-217.

Leibold, M. A. et al. 1997. Species turnover and the regulation of trophic structure. - Annu. Rev. Ecol. Syst. 28: 467-497.

Marquis, R. J. and Whelan, C. J. 1994. Insectivorous birds increase growth of white oak through consumption of leafchewing insects. - Ecology 75: 2007-2014.

Marquis, R. J. et al. 2002. Effect of plant architecture on colonization and damage by leaftying caterpillars of Quercus alba. - Oikos 99: 531-537.

Mazzarino, M. J. et al. 1998. Nutrient cycling in Patagonian ecosystems. - Ecol. Austral 8: 167-181.

Mazía, C. M. et al. 2004. Interannual changes in folivory and bird insectivory along a natural productivity gradient in northern Patagonian forests. - Ecography 27: 29-40.

Mazía, C. M. et al. 2009. Variable strength of top-down effects in Nothofagus forests: bird predation and insect herbivory during an ENSO event. - Aust. Ecol. 34: 359-367.

McArdle, B. H. and Anderson, M. J. 2001. Fitting multivariate models to community data: a comment on distance-based redundancy analysis. - Ecology 82: 290-297.

McQuillan, P. B. 1993. Nothofagus (Fagaceae) and its invertebrate fauna - an overview and preliminary synthesis. - Biol. J. Linn. Soc. 49: 317-354.

Menge, B. A. et al. 2002. Inter-hemispheric comparison of bottom-up effects on community structure: insights revealed using the comparative-experimental approach. - Ecol. Res. 17: $1-16$.
Moon, D.C. and Stiling, P. 2002. The influence of species identity and herbivore feeding mode on top-down and bottom-up effects in a salt marsh system. - Oecologia 133: 243-253.

Moon, D. C. and Stiling, P. 2004. The influence of a salinity and nutrient gradient on coastal vs upland tritrophic complexes. - Ecology 85: 2709-2716.

Moran, M. D. and Scheidler, A. R. 2002. Effects of nutrients and predators on an old-field food chain: interactions of top-down and bottom-up processes. - Oikos 98: 116-124.

Oksanen, L. et al. 1981. Exploitation ecosystems in gradients of primary productivity. - Am. Nat. 118: 240-261.

Polis, G. A. 1999. Why are parts of the world green? multiple factors control productivity and the distribution of biomass. - Oikos 86: 3-15.

Preszler, R. W. and Boecklen, W. J. 1996. The influence of elevation on tri-trophic interactions: opposing gradients of top-down and bottom-up effects on a leaf-mining moth. - Ecoscience 3: 75-80.

Richards, L. A. and Coley, P. D. 2007. Seasonal and habitat differences affect the impact of food and predation on herbivores: a comparison between gaps and understory of a tropical forest. - Oikos 116: 31-40.

Ritchie, M. E. 2000. Nitrogen limitation and trophic vs abiotic influences on insect herbivores in a temperate grassland. - Ecology 81: 1601-1612.

Schädler, M. et al. 2003. Does the Fretwell-Oksanen model apply to invertebrates? - Oikos 100: 203-207.

Schmitz, O. J. et al. 2000. Trophic cascades in terrestrial systems: a review of the effects of carnivore removals on plants. - Am. Nat. 155: 141-153.

Shurin, J. B. et al. 2002. A cross-ecosystem comparison of the strength of trophic cascades. - Ecol. Lett. 5: 785-791.

Sipura, M. 1999. Tritrophic interations: willows, herbivorous insects and insectivorous birds. - Oecologia 121: 537-545.

Stiling, P. and Rossi, A. M. 1997. Experimental manipulations of top-down and bottom-up factors in a tri-trophic system. - Ecology 78: 1602-1606.

Stiling, P. and Moon, D. C. 2005. Quality or quantity: the direct and indirect effects of host plants on herbivores and their natural enemies. - Oecologia 142: 413-420.

Stokes, M. A. and Smiley, T. L. 1968. An introduction to tree-ring dating. - Univ. of Chicago Press.

Strong, A. M. et al. 2000. Bird predation on herbivorous insects: indirect effects on sugar maple saplings. - Oecologia 125: 370-379.

Van Bael, S. et al. 2003. Birds defend trees from herbivores in a neotropical forest canopy. - Proc. Natl Acad. Sci. USA 100: 8304-8307.

Van Bael, S. et al. 2008. Birds as predators in tropical agroforestry systems. - Ecology 89: 928-934.

Veblen, T. T. et al. 1996. Ecology of southern Chilean and Argentinean Nothofagus forest. - In: Veblen, T. T. et al. (eds), The ecology and biogeography of Nothofagus forests. Yale Univ. Press, pp. 293-353.

Williams, I. S. 1999. Slow-growth, high-mortality - a general hypothesis, or is it? - Ecol. Entomol. 24: 490- 495.

Whitham, T. G. et al. 2006. A framework for community and ecosystem genetics: from genes to ecosystems. - Nat. Rev. Genet. 7: 510-523.

Worm, B. et al. 2002. Consumer versus resource control of species diversity and ecosystem functioning. - Nature 417: 848-851.

Yang, L. H. et al. 2008. What can we learn from resource pulses? - Ecology 89: 621-634. 


\section{Appendix 1}

Table A1. Folivore insect abundance, leaf damage rates, tree growth, and foliar traits for Nothofagus pumilio saplings in the dry forest. Values are means with SEs in parentheses.

\begin{tabular}{|c|c|c|c|c|c|c|c|c|}
\hline & \multicolumn{4}{|c|}{2005} & \multicolumn{4}{|c|}{2006} \\
\hline & \multicolumn{2}{|c|}{ Natural predation } & \multicolumn{2}{|c|}{ Bird exclusion } & \multicolumn{2}{|c|}{ Natural predation } & \multicolumn{2}{|c|}{ Bird exclusion } \\
\hline & Control & Fertilised & Control & Fertilised & Control & Fertilised & Control & Fertilised \\
\hline \multicolumn{9}{|c|}{ Abundance (no./100 leaves) } \\
\hline total folivores & $3.0(0.8)$ & $3.0(0.6)$ & $3.6(0.9)$ & $4.7(0.5)$ & $1.7(0.4)$ & $4.5(1.5)$ & $1.4(0.5)$ & $4.1(1.1)$ \\
\hline leaf miners & $\mathrm{n} / \mathrm{a}$ & $\mathrm{n} / \mathrm{a}$ & $\mathrm{n} / \mathrm{a}$ & $\mathrm{N} / \mathrm{a}$ & $0.5(0.3)$ & $2.8(1.4)$ & $0.4(0.3)$ & $2.0(1.1)$ \\
\hline leaf tiers & $2.9(0.8)$ & $3.0(0.6)$ & $3.5(0.9)$ & $4.6(0.5)$ & $1.1(0.2)$ & $1.5(0.3)$ & $0.9(0.2)$ & $2.1(0.4)$ \\
\hline Others & $0.1(<0.1)$ & $0.0(0.0)$ & $0.1(0.1)$ & $<0.1(<0.1)$ & $0.2(0.1)$ & $0.1(0.1)$ & $<0.1(<0.1)$ & $0.1(0.1)$ \\
\hline $\begin{array}{l}\text { Leaf damage } \\
\quad \text { frequency }(\%)\end{array}$ & $85.2(3.9)$ & $92.4(2.8)$ & $87.1(6.2)$ & $92.5(2.2)$ & $58.0(4.5)$ & $66.6(7.0)$ & $64.8(3.9)$ & $73.1(3.6)$ \\
\hline \multicolumn{9}{|l|}{ Leaf area damage $(\%)$} \\
\hline total folivores & 12.5 & $19.9(2.5)$ & $25.3(3.4)$ & $23.0(3.2)$ & $16.1(1.7)$ & $20.3(3.6)$ & $21.5(2.8)$ & $24.3(2.4)$ \\
\hline leaf miners & $4.4(0.9)$ & $5.9(1.5)$ & $11.0(3.1)$ & $5.2(0.9)$ & $8.8(1.3)$ & $10.3(2.8)$ & $13.5(2.1)$ & $12.5(2.1)$ \\
\hline skeletonizers & $3.3(0.9)$ & $5.9(1.4)$ & $6.1(1.2)$ & $8.0(2.4)$ & $4.2(0.6)$ & $5.3(0.7)$ & $5.1(0.8)$ & $6.3(0.9)$ \\
\hline leaf tiers & $1.6(0.6)$ & $4.6(1.1)$ & $5.7(1.4)$ & $5.6(1.1)$ & $2.3(0.6)$ & $4.2(1.2)$ & $2.3(0.8)$ & $4.5(0.8)$ \\
\hline $\begin{array}{l}\text { pit feeders (no. } \\
\text { holes/leaf) }\end{array}$ & $4.0(1.6)$ & $3.4(1.5)$ & $4.7(2.2)$ & $2.3(0.6)$ & $2.1(0.6)$ & $1.3(0.4)$ & $2.0(0.4)$ & $1.6(0.6)$ \\
\hline Tree growth (BAI ratio) & $1.39(0.10)$ & $1.44(0.10)$ & $1.27(0.16)$ & $1.44(0.08)$ & $1.82(0.17)$ & $2.23(0.32)$ & $1.38(0.23)$ & $1.92(0.09)$ \\
\hline Young leaves (\%) & $\mathrm{n} / \mathrm{a}$ & $\mathrm{n} / \mathrm{a}$ & $\mathrm{n} / \mathrm{a}$ & $\mathrm{n} / \mathrm{a}$ & $48.2(4.5)$ & $43.2(7.5)$ & $32.9(3.0)$ & $26.5(4.6)$ \\
\hline Leaf size $\left(\mathrm{cm}^{2}\right)$ & $3.3(0.3)$ & $3.2(0.3)$ & $3.0(0.2)$ & $3.0(0.1)$ & $2.8(0.2)$ & $3.4(0.2)$ & $3.1(0.3)$ & $3.7(0.3)$ \\
\hline $\mathrm{SLA}\left(\mathrm{mm}^{2} \mathrm{mg}^{-1}\right)$ & $17.8(2.6)$ & $13.9(0.7)$ & $15.6(0.5)$ & $15.9(1.5)$ & $12.2(0.8)$ & $14.6(1.5)$ & $14.9(2.1)$ & $14.4(1.6)$ \\
\hline Nitrogen $(\%)$ & $1.18(0.04)$ & $1.27(0.10)$ & $1.37(0.04)$ & $1.17(0.11)$ & $1.33(0.03)$ & $1.40(0.05)$ & $1.35(0.04)$ & $1.35(0.10)$ \\
\hline Phosphorus (\%) & $0.15(0.02)$ & $0.19(0.03)$ & $0.26(0.04)$ & $0.15(0.03)$ & $0.18(0.02)$ & $0.14(0.03)$ & $0.20(0.03)$ & $0.13(0.03)$ \\
\hline Potassium (\%) & $0.34(0.03)$ & $0.56(0.07)$ & $0.48(0.07)$ & $0.44(0.05)$ & $0.39(0.03)$ & $0.52(0.03)$ & $0.47(0.06)$ & $0.52(0.03)$ \\
\hline $\begin{array}{l}\text { Total phenols } \\
\quad\left(\mathrm{mg} \mathrm{g}^{-1}\right)\end{array}$ & $\mathrm{n} / \mathrm{a}$ & $\mathrm{n} / \mathrm{a}$ & $\mathrm{n} / \mathrm{a}$ & $\mathrm{n} / \mathrm{a}$ & $12.6(2.2)$ & $14.2(4.3)$ & $12.5(1.5)$ & $15.1(3.2)$ \\
\hline Toughness $\left(\mathrm{g} \mathrm{mm}^{-2}\right)$ & $35.2(13.1)$ & $38.5(9.1)$ & $41.1(10.4)$ & $17.2(3.0)$ & $66.5(1.8)$ & $62.4(2.1)$ & $68.2(2.9)$ & $67.8(4.1)$ \\
\hline
\end{tabular}

Table A2. Folivore insect abundance, leaf damage rates, tree growth, and foliar traits for Nothofagus pumilio saplings in the wet forest. Values are means with SEs in parentheses.

\begin{tabular}{|c|c|c|c|c|c|c|c|c|}
\hline & \multicolumn{4}{|c|}{2005} & \multicolumn{4}{|c|}{2006} \\
\hline & \multicolumn{2}{|c|}{ Natural predation } & \multicolumn{2}{|c|}{ Bird exclusion } & \multicolumn{2}{|c|}{ Natural predation } & \multicolumn{2}{|c|}{ Bird exclusion } \\
\hline & Control & Fertilised & Control & Fertilised & Control & Fertilised & Control & Fertilised \\
\hline \multicolumn{9}{|c|}{ Abundance (no./100 leaves) } \\
\hline total folivores & $0.1(0.1)$ & $0.4(0.2)$ & $0.7(0.2)$ & $0.2(0.1)$ & $3.9(0.8)$ & $4.6(0.8)$ & $4.1(1.1)$ & $6.9(0.9)$ \\
\hline leaf miners & $\mathrm{n} / \mathrm{a}$ & $\mathrm{n} / \mathrm{a}$ & $\mathrm{n} / \mathrm{a}$ & $\mathrm{n} / \mathrm{a}$ & $3.7(0.8)$ & $4.3(0.7)$ & $3.6(1.1)$ & $6.5(0.8)$ \\
\hline pit feeders & $0.02(0.02)$ & $0.00(0.00)$ & $0.12(0.06)$ & $0.00(0.00)$ & $0.04(0.02)$ & $0.01(0.01)$ & $0.05(0.04)$ & $0.03(0.02)$ \\
\hline others & $0.1(0.1)$ & $0.4(0.2)$ & $0.6(0.2)$ & $0.2(0.1)$ & $0.2(0.1)$ & $0.3(0.1)$ & $0.5(0.1)$ & $0.3(0.2)$ \\
\hline $\begin{array}{l}\text { Leaf damage } \\
\quad \text { frequency }(\%)\end{array}$ & $61.8(4.8)$ & $55.3(2.5)$ & $49.4(4.1)$ & $53.2(7.3)$ & $74.1(3.3)$ & $74.2(4.7)$ & $71.2(2.2)$ & $67.9(6.1)$ \\
\hline \multicolumn{9}{|l|}{ Leaf area damage $(\%)$} \\
\hline total folivores & $3.8(0.8)$ & $3.9(0.6)$ & $2.3(0.3)$ & $2.1(0.5)$ & $8.4(0.8)$ & $9.1(1.0)$ & $7.6(0.6)$ & $7.5(1.7)$ \\
\hline leaf miners & $0.1(<0.1)$ & $1.0(0.7)$ & $0.2(0.1)$ & $0.1(0.1)$ & $0.7(0.2)$ & $1.3(0.3)$ & $1.1(0.2)$ & $1.5(0.4)$ \\
\hline skeletonizers & $0.6(0.2)$ & $0.7(0.3)$ & $0.5(0.1)$ & $0.6(0.1)$ & $6.9(0.8)$ & $6.8(1.2)$ & $5.4(0.4)$ & $5.1(1.3)$ \\
\hline $\begin{array}{l}\text { pit feeders (no. } \\
\text { holes/leaf) }\end{array}$ & $1.3(0.2)$ & $1.5(0.3)$ & $2.7(0.7)$ & $2.1(0.7)$ & $5.2(0.6)$ & $4.6(1.4)$ & $12.4(2.6)$ & $7.7(2.0)$ \\
\hline Tree growth (BAI ratio) & $1.28(0.10)$ & $0.92(0.08)$ & $1.35(0.09)$ & $1.05(0.10)$ & $1.47(0.15)$ & $1.37(0.14)$ & $1.32(0.24)$ & $1.35(0.12)$ \\
\hline Young leaves $(\%)$ & $4.0(0.7)$ & $2.8(0.6)$ & $2.3(0.4)$ & $2.2(0.7)$ & $44.3(2.3)$ & $37.5(3.7)$ & $28.7(3.0)$ & $29.3(3.3)$ \\
\hline Leaf size $\left(\mathrm{cm}^{2}\right)$ & $4.5(0.2)$ & $3.9(0.2)$ & $4.3(0.2)$ & $4.0(0.3)$ & $3.4(0.2)$ & $3.6(0.2)$ & $3.8(0.2)$ & $4.0(0.3)$ \\
\hline $\operatorname{SLA}\left(\mathrm{mm}^{2} \mathrm{mg}^{-1}\right)$ & $16.4(0.8)$ & $17.9(2.3)$ & $16.9(1.2)$ & $15.7(0.9)$ & $15.8(0.6)$ & $18.1(1.8)$ & $16.4(1.5)$ & $16.9(1.5)$ \\
\hline Nitrogen $(\%)$ & $1.47(0.10)$ & $1.44(0.13)$ & $1.62(0.11)$ & $1.50(0.10)$ & $1.17(0.07)$ & $1.29(0.12)$ & $1.08(0.08)$ & $1.49(0.13)$ \\
\hline Phosphorus (\%) & $0.25(0.03)$ & $0.33(0.05)$ & $0.34(0.03)$ & $0.34(0.04)$ & $0.19(0.01)$ & $0.22(0.02)$ & $0.21(0.02)$ & $0.22(0.03)$ \\
\hline Potassium (\%) & $0.48(0.05)$ & $0.66(0.07)$ & $0.57(0.04)$ & $0.57(0.05)$ & $0.43(0.04)$ & $0.72(0.07)$ & $0.44(0.04)$ & $0.72(0.05)$ \\
\hline $\begin{array}{l}\text { Total phenols } \\
\qquad\left(\mathrm{mg} \mathrm{g}^{-1}\right)\end{array}$ & $19.3(4.4)$ & $12.9(5.0)$ & $16.8(7.3)$ & $16.3(7.4)$ & $7.1(0.6)$ & $4.0(0.9)$ & $7.2(1.5)$ & $9.9(2.6)$ \\
\hline Toughness $\left(\mathrm{g} \mathrm{mm}^{-2}\right)$ & $22.9(4.1)$ & $23.6(5.5)$ & $24.0(3.5)$ & $25.6(5.2)$ & $50.5(1.1)$ & $48.8(1.8)$ & $48.5(2.5)$ & $48.4(2.0)$ \\
\hline
\end{tabular}

